\title{
JOURNAL.RU
}

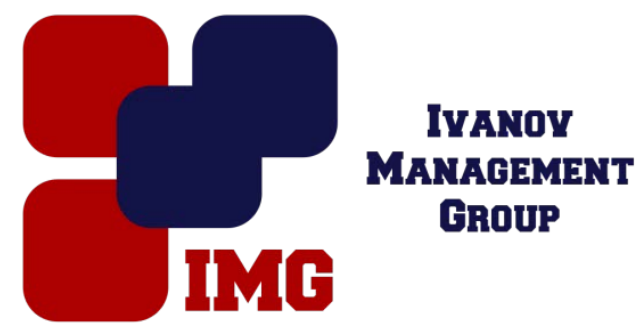

Kochetova G. R. The Branch of the Federal State Budgetary Educational Institution of Higher education "Ufa State Aviation Technical University" in Kumertau Kumertau, Russia

doi: 10.18411/lj-31-03-2017-2-15

idsp 000001:lj-31-03-2017-2-15

\section{Experimental research of the associative coloring of the sound-letters}

\begin{abstract}
s
This article deals with the associative experiment that continues to remain one of the most developed approaches to the analysis of the person's speech organization. The associative experiment is used at studying the associative memory of men being tested, associative processes occurring in mental lexicon for the establishment of associative communications between the words during the research of collective and individual consciousnesses. The research of associations represents a great interest whereas associations make the most important basis of a human life without which the person cannot exist.

Key words: associative experiment, associative coloring, sound-letters, the Bashkir language, the Tatar language

The subject of this work was established experimental way by associative coloring of the sound-letters of the Bashkir and Tatar languages as the unit of the analysis for studying displays of the internal form of the verbal model. We have defined that the internal form of the word reflects its motivation by the other language elements and consequently partly explains its semantic structure.

Under the verbal model we understand the any materialized model being the carrier of the internal form through which in an environment realized the latent informativity and the influencing potential of the concrete model. That is why the associative chromaticity of the sound-letters is one of displays of the internal form which established by means of verbal associations.
\end{abstract}


From 2010 till 2012 we had been lead free associative experiments. It's purpose was the creation of color matrixes of the Bashkir and Tatar languages. By means of the received matrixes it is possible to explain various and disembodied data about dynamic laws functioning of a word in the individual creation.

There were 400 examinees who have taken part in the experiment - everyone are informants of the Bashkir and Tatar languages who are not only own oral speech, but freely write and read in native language for them. The native language is the language of daily dialogue for them. Middle age of examinees - 17-27 years. The total quantity of the analysed answers of examinees has made 4482 associative reactions.

The associative experiment has allowed: to define the associative coloring of the Bashkir and Tatar language sound-letters; to make color matrixes of the Bashkir and Tatar language sound-letters; to reveal similar under the description and associative coloring of the sound-letters of the Russian, Bashkir and Tatar languages; to create the computer program of the automated analysis of a word and the text; to approve the computer program on a material of prayerful texts.

The similar analysis of associative coloring of the Bashkir and Tatar languages was carried out for the first time. In investigated languages we have tried to allocate sound-letters similar on pronunciation and descriptive characteristics, thus we compared only the description of the letter and their psychological (associative) coloring. Data of the quantitative analysis and qualitative interpretation of stimulus row and associations have allowed us to specify the received parameters of color matrixes of languages that are the basic component of the program of the automated analysis of a word and the text «BATYR».

In 2013 a group of authors (the head of the project T.M. Rogozhnikova, the programmer D.D. Kudashov, G.R. Kochetova, N.V. Efimenko) has developed the computer program «BATYR». The main component of which includes the color matrixes of the Bashkir and Tatar language sound-letters. The program is written in Delphi language integrated into CodeGearRADStudio 2009 processing system. The program implements 12 functions.

The associative coloring of the sound-letters as the display of the internal form of verbal model demands further deep studying. The special importance for the theory of language, in our opinion, represent further interlingual researche spent on different languages. The prospects of this research we can see in an opportunity of carrying out interlingual comparison, revealing of universal mechanisms of functioning of a word in an individual lexicon. 


\section{Литература}

1. Кочетова Г.Р. Ассоциативная цветность как проявление внутренней формы вербальной модели: дис. ...канд. филол. наук: 10.02.19./ Г.Р. Кочетова. - Уфа, УГАТУ, 2014. - 184 c.

2. Рогожникова Т.М, Кудашов Д.Д., Кочетова Г.Р., Ефименко Н.В. Программа для ЭВМ «БАТЫР» (Автоматизированный анализ слова и текста): Свидетельство о гос. регистрации программы для ЭВМ № 2014613238, М., 2014 http://www1.fips.ru/wps/portal/IPS_Ru\#1473534875815 